DOI: $10.14746 /$ por.2018.2.10

\title{
MITOLOGIE CZAJKI
}

\author{
Marta TomczoK ${ }^{1}$ \\ (Uniwersytet Śląski w Katowicach)
}

\begin{abstract}
Słowa kluczowe: Izabela Czajka Stachowicz, polsko-żydowska artystka, surrealizm, stygmatyzacja, self-esteem, totemizm Keywords: Izabela Czajka Stachowicz, Polish-Jewish artist, surrealism, stigmatisation, self-esteem, totemism
\end{abstract}

\begin{abstract}
Abstrakt: Marta Tomczok, MITOLOGIE CZAJKI. „PORÓWNANIA” 2 (23), 2018. T. XXIII, S. 139-150. ISSN 1733-165X. W artykule omawiam zjawisko mitologii polsko-żydowskiej artystki, aktywnej przede wszystkim w drugiej połowie XX wieku. Jest to mitologia "długiego trwania”, sięga bowiem czasów dwudziestolecia międzywojennego, surrealizmu, awangardy i warszawskiej cyganerii artystycznej. Przykładu dostarcza mi proza Izabeli Czajki Stachowicz, a także wypowiedzi krytyków literackich i publicystów: Jana Kotta, Krystyny Kolińskiej i Ryszarda Matuszewskiego. Omawiając stereotypy płciowe i stygmaty, jakimi opisywano po wojnie twórczość Czajki, staram się pokazać negatywne aspekty jej mitologii. Z kolei w jej prozie szukam reakcji na stygmatyzację w postaci symboli rzeczy i zwierząt (totemizm).
\end{abstract}

Abstract: Marta Tomczok, CZAJKA'S MYTHOLOGIES. "PORÓWNANIA" 2 (23), 2018. Vol. XXIII, P. 139-150. ISSN 1733-165X. In this article I discuss the phenomenon of the mythology of a Polish-Jewish active artist in the second half of the twentieth century. This is a mythology of "long duration", because it goes back to the interwar period, surrealism, avant-garde and Warsaw's Bohemia. The example is provided by prose from Izabela Czajka Stachowicz but also statements of literary critics and journalists of Jan Kott, Krystyna Kolińska, and Ryszard Matuszewski. By means of discussing gender stereotypes and stigmas that the works of Czajka were described with after the war, I try to show the negative aspects of her mythology. In turn, I am looking for a reaction to stigmatization in the form of symbols of objects and animals in her prose.

1 E-mail: martacuber@interia.pl 


\section{Mitologia artystki jako rezerwuar stygmatów}

W artykule zamierzam omówić i przeanalizować mitologię polsko-żydowskiej artystki ukształtowaną po zakończeniu drugiej wojny światowej. Nie jest to mitologia odległa od przedwojennych opowieści o kobietach z kręgu kultury żydowskiej. Wydaje się raczej $\mathrm{w}$ nich zakorzeniona, spowinowacona $\mathrm{z}$ nimi, a nawet od nich zależna. Przez mitologię proponuję rozumieć zarówno zbiór fikcyjnych przeświadczeń na własny temat, służący zbudowaniu od nowa własnej tożsamości, a odpowiadający w jakiejś mierze ogólnej naturze sztuki, jak i autonarrację mającą na celu ukształtowanie self-esteem. Niestety, mitologia bywa również rezerwuarem stereotypów i społecznych urojeń, a przede wszystkim obszarem stygmatyzacji. Dlatego narrację, służącą zburzeniu jednych mitów o polsko-żydowskiej artystce i wytworzeniu oraz podtrzymaniu innych, należałoby opisywać jako narrację dwuwymiarową. Składać się na nią będą z jednej strony wypowiedzi tzw. aktorów, czyli obserwatorów i komentatorów działania artystycznego odnotowane w prasie literackiej, wspomnieniach, podręcznikach do historii literatury, z drugiej strony autonarracja będąca wytworem tzw. osoby w sposób umotywowany opowiadającej swoją historię; może ona przyjąć postać dowolnej wypowiedzi artystycznej.

Podkreślając, że mitologia powojennej artystki żydowskiej powinna stanowić przedmiot szeroko zakrojonych badań humanistycznych i społecznych, odwołujących się do takich dyscyplin jak literaturoznawstwo, socjologia (stereotypy, tożsamość, self-esteem, żydowskość) czy psychologia (autonarracja), staram się przede wszystkim pokazać, jak złożonym zjawiskiem jest sama mitologia. W opracowaniu z 1978 roku Andrzej Osęka przedstawiał ją następująco:

Zadanie, jakie sobie stawiam: poznać pewną sumę wyobrażeń o artyście, zastanowić się, jak funkcjonują one w świadomości społecznej, może się wydawać zbliżone do celów rozpowszechnionej dziś w socjologii, w antropologii tzw. „,analizy mitu”. Jest to podobieństwo pozorne. [...] Jeśli można sumę wyobrażeń o artyście, nadziei związanych $z$ istnieniem artysty nazwać $[\ldots]$ mitem - jest to moim zdaniem jeden $\mathrm{z}$ tych niewielu mitów, które są i pozostaną żywe. [...] Zawsze człowiek tworzący piękno będzie w oczach innych, a także własnych, istotą tajemniczą, wyjątkową (Osęka 20-21).

Czterdzieści lat później pozostawienie tego stwierdzenia bez komentarza wydaje się niemożliwe. Po pierwsze, artysta od dawna przestał być postrzegany jako osoba tworząca wyłącznie piękno. Sama kategoria piękna uległa od tego czasu licznym przekształceniom. Po drugie, zmieniły się oczekiwania artysty, narosło wokół nich także wiele nowych, niekiedy jeszcze bardziej fałszywych narracji, wywodzących się nie tylko z historii sztuki (co próbował pokazać Osęka, odwołując się do tradycji renesansu, romantyzmu czy pop-artu), ale także wynikających z oddziaływania na współczesne społeczeństwo nowych mediów, ułatwiających współkształtowanie 
kategorii takich jak sława czy miłość tłumów. Opinii Osęki nie sposób przyjąć bezkrytycznie także dlatego, że tkwi w niej przeświadczenie, iż tajemniczość i wyjątkowość artysty są czymś społecznie oczekiwanym i pożądanym, a zatem wartościowanym pozytywnie. Tymczasem artystyczne uniwersum pełne jest także mitów nieprzejrzanych, funkcjonujących w charakterze stygmatu bądź piętna.

Pojęciem "stygmat społeczny" będę się posługiwać za Elżbietą Czywkin i Małgorzatą Melchior. Pierwsza z badaczek - w wyniku polemiki z pracą drugiej przyjmuje, że „stygmat ma charakter jednostkowy, ale przede wszystkim grupowy (kategoria społeczna), stanowiący rezultat podziałów na swoich i obcych (grupę in i out)" (Czywkin 26). Z kolei stygmatyzacja to „obszar zagadnień znaczenie szerszy, przekraczający znaczeniowe ujęcie przydawane etykietowaniu, np. stereotypizację, ukrywanie stygmatu, destygmatyzację, płaszczyzny stygmatyzacji i inne" (Czywkin 26). W artykule Melchior pojęcie stygmatyzacji jest stosowane wymiennie $\mathrm{z}$ „etykietą" i „piętnem”, a odnosi się przede wszystkim do zachowań antysemickich, czyniących z określenia Żyd coś upokarzającego, wstydliwego, poniżającego:

Etykiety stają się $\mathrm{w}$ pewnych warunkach określeniami stygmatyzującymi, piętnami: ich użycie wobec jednostki wyłącza ją z grona „swoich” czy „normalnych”. Jednostka napiętnowana to jednostka, którą coś dyskwalifikuje, przeszkadza w zaakceptowaniu przez otoczenie (Melchior 2001: 263).

Stygmatyzacja dotyczy przede wszystkim osób przewlekle chorych i wyłączonych z codziennych aktywności (nowotwory, AIDS), niepełnosprawnych, cudzoziemców i imigrantów, Żydów, kobiet, ludzi otyłych, starszych, matek samotnie wychowujące dzieci, alkoholików czy bezrobotnych (Czywkin 45-46; Czywkin, Rusaczyk). Nie jest więc kojarzona i zestawiana z mitologią artystyczną, która z kolei, jak pokazuje przykład opracowania Osęki, ma przede wszystkim wymiar pozytywny. Nie oznacza to jednak, że takie porównanie będzie błędem albo rażącym naruszeniem porządku terminologicznego. Wśród cech stygmatyzacji wymienia się między innymi inercję $\mathrm{w}$ czasie (nawet osoba wyleczona może nosić stygmat chorej), nieracjonalność, ambiwalencję i oślepiającą funkcję stygmatu (stanowiącego swoiste logo stygmatyzowanego, poza którym nie widać już żadnych innych jego cech) (Czywkin 38-45). Wynika stąd, że stygmatyzacja jest zjawiskiem niejednoznacznym, trudnym w ocenie i opisie, a przede wszystkim nie zawsze właściwie identyfikowanym zarówno przez obiekt upokorzenia, jak i jego sprawców.

Bodaj najszerzej znanym (a przy okazji też bardzo efektownym) przykładem stygmatu oddziałującego na mitologię polsko-żydowskiej artystki jest kategoria pięknej Żydówki. „Stygmatem jej symbolicznej biografii - pisała Maria Janion o Zuzannie Ginczance - staje się «piękna Żydówka», stygmatem jej twórczości jeden wiersz, odczytywany w tradycji męczeńskiej. To jest właściwie ten sam stygmat" (Janion 7). Neutralizowanie takiej kategorii - mimo twardego stanowiska Jean-Paula 
Satre'a czy pracy Bożeny Umińskiej Portret Żydówki z cieniem - ma niewątpliwie związek z jej „efektownością", czyli nieprzejrzystym społecznym oddziaływaniem ukształtowanego w ten sposób obrazu. Wystarczy jednak go odwrócić - co zrobię z autonarracjami Izabeli Czajki Stachowicz, w których obecna jest zarówno przedwojenna, jak i powojenna mitologia - aby zobaczyć, w jaki sposób piękna młodość zmienia się w otyłą, groteskową starość $\mathrm{i}$ traci zainteresowanie publiczności, wywołując głównie napastliwe reakcje.

Wydawana przede wszystkim w latach sześćdziesiątych proza wspomnieniowa Czajki Stachowicz idealnie nadaje się do obserwacji stereotypów, jakimi obrosły mitologie artystyczne XX wieku, a szczególnie mitologie kobiet. Jest to bowiem proza prawie $\mathrm{w}$ całości poświęcona dwudziestoleciu międzywojennemu. W myśl przyjętych założeń należy ją czytać jako narrację umacniającą poczucie wartości pisarki; wytworzone w niej mity miały na celu zwalczać i dekonstruować społeczne stygmaty, na których została oparta mitologia złożona z reakcji na literaturę Czajki. Jej najważniejszymi elementami są: żydowskość, kobiecość, starość, otyłość i głupota. Pisarka przetwarza je w obrazy symboliczne, służące wzmocnieniu Ja i jego obronie. $\mathrm{W}$ artykule omówię trzy przykłady tego typu działań, pochodzące z powieści wydanych w latach 1956-1969. Żaden z nich nie odpowiada bezpośrednio konkretnemu stygmatowi. Walka, jaką wydała im autorka, podobnie jak jej radzenie sobie ze stygmatyzującą mitologią, ma charakter internalizacji i tylko na poziomie metafor bądź symboli należy szukać odpowiedzi na pytanie o mitologię artystyczną w jej twórczości.

\section{Wypowiedzi aktorów i obserwatorów}

„Stygmat, jeśli istnieje bez «społecznego lustra», nie jest tak niszczący dla Ja, jak w przypadku jego braku" (Czywkin 143). Przedwojenna kariera Czajki Stachowicz miała znamiona celebryctwa (Godzic). Nie wynikała z jakichś konkretnych przesłanek, materialnych dowodów, niezwykłych artefaktów, ale raczej ze świadomie wyreżyserowanego przez przyszłą pisarkę widowiska. Przypomnijmy role, jakie Czajka odegrała w literaturze dwudziestolecia międzywojennego - Heli Bertz z Pożegnania jesieni Stanisława Ignacego Witkiewicza i Panny Leopard ze Wspólnego pokoju Zbigniewa Uniłowskiego ${ }^{2}$. Obie one zostały opracowane przez mężczyzn jako pełne seksistowskich stereotypów (Mandal 13-15), a ich rangę i wartość literacką umocnił dyskurs historycznoliteracki pozbawiony wrażliwości etycznej i epistemicznej.

Dominująca w micie żydowskiej piękności bierność zwykle nie występuje w przedstawieniach Czajki, pojawia się za to sprawczość kobiecego podmiotu,

2 Niewiele niestety wiadomo na temat reakcji Czajki na powieści Uniłowskiego i Witkacego. Można jedynie snuć domysły, że nie wszystko w nich akceptowała. 
którą krytycy tacy jak Jan Kott zamkną później w stereotypie opisującym jeszcze inną kobiecą mitologię artystyczną pierwszej połowy ubiegłego wieku: nastoletniej muzy surrealistów (Kott 6). Do najważniejszych komponentów wspomnianej mitologii należą: intuicyjność działania, niedorosłość, genialność, poezja, inspirowanie twórców-mężczyzn, możliwość natychmiastowego wycofania się z roli czy podporządkowanie światu dorosłych, decydujących o porządku w sztuce artystów (Taborska).

Publiczny wizerunek Czajki, skonstruowany we wspomnieniach czy literaturze, wydaje się, w porównaniu z Ginczanką i surrealistkami takimi jak Gisèle Prassinos, przeładowany erotyzmem, kpiną, irytacją i złośliwościami. „Hela Bertz była oczywiście Żydówką i wcieleniem wszystkiego tego, co Atanazemu w kobiecie jako takiej podobać się mogło. Prócz tego była, aż do pewnych nieprzekraczalnych granic, kobietą notorycznie łatwą" (Witkiewicz 11-12)33 ; "Bydlę, bydlę, nędzna dziwka" (Uniłowski 85). Autorzy wydanej w 2011 roku antologii komiksu Złote pszczoty, poświęconej między innymi żydowskim zasłużonym mieszkańcom Warszawy, przedstawiają autorkę Pieśni żałobnych getta jako smukłą, długonogą i zawadiacką piękność przebraną w skórę geparda. Niestety, trudno ocenić tę kreację jako wolną od stereotypu. Widzimy Czajkę przede wszystkim w otoczeniu mężczyzn - ojca Wilhelma Szwarza, przyjaciół Skamandrytów, Witkacego. Uzależnienie od oceny męskiego spojrzenia, w wyniku którego rozerotyzowana, niepisząca artystka, rujnująca żydowską fortunę na kaprysy „zdolniejszych” kolegów przechodzi do legendy, staje się fundamentem jej artystycznego mitu. Dodajmy jednak, że jest to mit, z którym pisarka po wojnie na różne sposoby walczyła.

Jak kształtuje się jej pozagładowa mitologia? Tworzy ją jeszcze więcej stygmatów i stereotypów. Podstawowe z nich to wymienione już starość, kobiecość, otyłość i żydowskość. Analizę ograniczę do dwu wypowiedzi wpływowych krytyków literackich powojnia: Kotta i Ryszarda Matuszewskiego.

Bela była sławniejsza od wielu pisarzy, chociaż sama nie napisała ani jednej książki. Ale wiele książek na pewno bez niej by nie powstało [...]. Wyobrażamy sobie zawsze, że Muza powinna być podobna do Beatrycze. Powinna być cicha i marząca, wiotka i poetyczna, mieć jasne włosy i niebieskie oczy. Nie wiem, czy Beatrycze istniała naprawdę i pewno wcale nie miała niebieskich oczu. Bela jest duża i czarna. Była Muzą zupełnie innego rodzaju. Jest gwałtowna i nie znosi sprzeciwu... (Kott 6, podkr. M.T.).

[...] Bela, coś w rodzaju żeńskiej i na pewno uboższej wersji słynnego Franca Fiszera, wielkiej legendy życia kawiarnianego lat międzywojennych, miała za sobą krótkotrwałe małżeństwo z Aleksandrem Hertzem, poważnym socjologiem, [...] którego osobowość

3 Jak pisała Bożena Umińska: „[...] Hela jako kobieta nie może być artystką [...]. Artystami bywają tylko mężczyźni" (Umińska 211). 
wydawała mi się wręcz antytezą jej nieco wyzywającej postaci [...]. To coś tak, jakby na przykład profesor Kotarbiński pojął za żonę primadonnę z operetki [...].

Jeżeli przedwojenne wcielenie Beli, w której uszminkowanych ustach każdy fakt zmieniał się w barwną, silnie podkoloryzowaną anegdotę, było czymś nieopisanie zabawnym, to widok jej obfitych kształtów obleczonych w wojskowy mundur w Lublinie jesienią 1944 roku miał nieskończenie bardziej groteskowy charakter. [...] Ostry jak zwykle makijaż w zestawieniu z mundurem "ludowej armii” i zamaszyste kołysanie biodrami - zwielokrotniały efekt tej patriotycznej przebieranki (Matuszewski 2004: 73-74, podkr. M.T.).

W opinii Kotta przeważają peryfrazy („duża”, „czarna”), natomiast w wypowiedzi Matuszewskiego pojawiają się sformułowania dosłowne („obfite kształty”, "groteskowy charakter"). Z punktu widzenia stygmatyzacji i jej oswajania unikanie nazewnictwa piętnującego i zastępowanie go określeniami łagodniejszymi jest drogą donikąd (Czywkin 28). „Strategia oswajania i racjonalizowania werbalnych ekwiwalentów" (Czywkin 28) nie powinna naruszać ich tkanki słownej. Jak wynika jednak z obu opisów, ich autorzy sprawnie (i względnie poprawnie) zrekonstruowali przedwojenną mitologię Czajki, nazywając ją "czymś nieopisanie zabawnym”. Nie poradzili sobie natomiast ze zjawiskiem monstrualizacji, polegającym na lekceważeniu cech dojrzałej kobiecej osobowości, za pomocą których podmiot decyduje o sobie, i przekształcaniu ich w narrację odstraszającą, przerażającą oraz pozbawioną jakichkolwiek walorów. Jest ona wyrazem bezradności otoczenia wobec aktywności monstrualizowanego podmiotu. W szczególnych przypadkach wydaje się także reakcją mężczyzn na kobiecą dojrzałość i starość.

W pracy niemieckiego psychiatry Manfreda Spitzera pojawia się interesujący przykład kenijskich słonic. Z obserwacji naukowców wynika, że dzięki doświadczeniu i szacunkowi otoczenia przewodniczka stada, zbierająca i przetwarzająca dziesiątki komunikatów pochodzących od mijanych w ciągu roku słoni z obcych stad, jest w stanie nie tylko ochronić swoją grupę, w tym szczególnie osobniki młode, ale także przyczynić się do jej sukcesu reprodukcyjnego. „To, że kobiety mają większe kompetencje społeczne niż mężczyźni i dłużej żyją, w świetle tych danych może nie być przypadkiem” (Spitzer 205-206).

Sięgam po ten przykład, aby pokazać, jak różnie mogą być oceniane starość, duża masa ciała czy kobiecość i że oceny te kształtują się w zależności od opisywanego gatunku zwierząt, narzędzi opisu, obszaru nauki, w ramach której powstaje taki opis, a przede wszystkim - stopnia nasycenia go erotyką. W przypadku relacji Spitzera jest on bliski zeru, choć opowieść o słonicach dotyczy także ich rozmnażania się. Układem odniesienia dla mitu otyłej, ciemnej Żydówki jest natomiast jej niewinna młodość. Dlatego mężczyźni widzą go w kategoriach braku, a nie dostatku. Istnieje jeszcze jeden powód deprecjonowania wizerunku starej artystki. Jest nim defekt kultury patriarchalnej, której częścią wciąż pozostaje kultura polska, polega- 
jący na uniemożliwianiu kobietom, które utraciły atrybuty fizycznej atrakcyjności, poczucia własnej godności (Janion 2001). „Obraz starej kobiety tworzony w literaturze przez starych mężczyzn pokazuje, że stary facet nie uważa starej kobiety za swój odpowiednik, ona nie jest dla niego parą. Do starego mężczyzny pasuje natomiast młoda kobieta" (Janion 2001). Warto zauważyć, że publikacja Matuszewskiego zatytułowana Alfabet. Wybór z pamięci 90-latka, w której znalazło się kilka ciepłych portretów młodszych intelektualistek, jedynie potwierdza tę regułę.

Od stereotypów i stygmatów nie są wolne także dwie opowieści biograficzne o Czajce Stachowicz: Szatańska księżniczka Krystyny Kolińskiej i Ta piękna mitomanka Pauliny Sołowianiuk. Na treści piętnujące bohaterkę wskazują już ich tytuły, nawiązujące do obiegowych opinii o pisarce, związanych z Witkacym z jednej strony i jej talentem narracyjnym, mylonym przez niektórych z konfabulacją, z drugiej. Kolińska i Sołowianiuk przypominają jeszcze jeden krzywdzący wizerunek Czajki - jako artystki przesadnie skoncentrowanej na swoim pięknym ciele. Z okładki Szatańskiej księżniczki spoglądają obramowane żółtym kolorem czarne oczy, pod którymi rysują się karminowe usta. Warto jednak przypomnieć za Joanną Tokarską-Bakir, że kolor żółty przynajmniej od czasów średniowiecza służył upokarzaniu i stygmatyzowaniu Żydów (Tokarska-Bakir 17). Co innego zresztą, jeśli nie hańbę, miałaby oznaczać barwa żółta, niezmiernie rzadko umieszczana przez kobiety na powiekach w postaci ozdobnych cieni? Stygmatyzujący charakter drugiej okładki wydaje się jeszcze bardziej widoczny. "Na obwolucie [...] wykorzystano zdjęcie przedstawiające Izabelę Czajkę-Stachowicz pozującą studentom Akademii Sztuk Pięknych w 1947 roku, pochodzące ze zbiorów Muzeum Literatury w Warszawie" (Sołowianiuk 4). Nie widać jednak na nim całej Czajki, a jedynie jej nagą pupę i nogi, którym przyglądają się stojący poniżej modelki panowie i pojedyncze panie. Wybór akurat takiego zdjęcia na okładkę książki o twórczości Czajki Stachowicz - postaci przesadnie mitologizowanej, przesłoniętej najróżniejszymi legendami i przede wszystkim, o czym pamiętał nawet Matuszewski, zapomnianej - należy uznać za przejaw złej woli autorki opracowania. Stygmat "pięknej mitomanki” odbiera bowiem całą powagę jej twórczości i przekierowuje uwagę odbiorcy na treści - chciałoby się rzec - bulwarowe.

Kobiety, podobnie jak osoby czarnoskóre czy Żydzi, należą do grupy zagrożonej stereotypizacją. Jedno z ważniejszych, kierowanych przeciwko nim uprzedzeń ma na celu zakwestionowanie ich umiejętności abstrakcyjnego myślenia i zdolności matematycznych (dotyka ono przede wszystkim osób czarnych i kobiet; Czywkin 246). Ludzie napiętnowani wyłączają często z obrazu samych siebie sferę piętnowanych osiągnięć. Dzieje się tak nawet wtedy, gdy są to osiągnięcia znaczące. Proces dezidentyfikacji (Czywkin 247) prowadzi do wniosku, że stygmatyzowani w obawie przed krzywdzącym wymiarem stereotypu są w stanie odseparować od siebie wszystkie jego podstawy, łącznie z tymi, które mogłyby stanowić dla nich wymierną korzyść. 
W twórczości Czajki widać swoistą grę z uprzedzeniami (jej przykłady omówię w ostatniej części artykułu). Teraz jednak warto zająć się kilkoma uwagami z książki Kolińskiej, mającymi znamiona przemocy antyfeministycznej i antysemickiej. Publicystka uznała na przykład spotkanie Brunona Schulza z Czajką za mało prawdopodobne, insynuując, że pisarz, skądinąd obdarzony specyficznymi skłonnościami wobec kobiet, mógłby nie być zainteresowany zbyt „głupią" artystką:

Wydaje się, że typ wspaniałej, głębokiej inteligencji autora Sanatorium pod Klepsydra, materiał jego życia i jego twórczości, wewnętrzne alchemie, artystyczne przewrotności, perwersje musiały być zbyt zagmatwane dla prostej w gruncie rzeczy jej natury, zbyt trudne w złożoności, nieprzydatne dla niej jako źródło do wytwarzania musujących pianek rozważań, żartów, literackich gier i zabaw (Kolińska 25, podkr. M.T.).

Jeszcze dalej Kolińska posunęła się w ocenie erotycznego temperamentu artystki, umieszczając go między oziębłością frygidy a gorącem hurysy:

A więc jak to właściwie wyglądało: czy była omdlewająca, perwersyjnie erotyczna jak panna Leopard, czy pełną dzikiej namiętności hurysą na łożach szejków, maharadżów, nałożnicą Matisse'ów i Modiglianich, metresą francuskich poetów i rosyjskich tancerzy, którzy rzucali dla niej młodych chłopców? Czy raczej - w gruncie rzeczy - frigida, udającą mistrzowsko, że spala się w ogniu żądzy... Dawałam się nieść prądowi i falowałam we wszystkich kierunkach - mówiła nieraz - żyć chciałam, goniłam za wszystkim, co mogło mnie zbawić, upoić i ubarwić mój świat (Kolińska 69).

Tego typu uwagi niewiele wnoszą do stanu wiedzy o Czajce, pokazują za to patologiczną wyobraźnię publicystki, przypisującej sobie kompetencje, by bez użycia cudzysłowu (re)konstruować słowa swojej bohaterki. Czajka nie mogła jej odpowiedzieć (choć niewykluczone, że się znały), podobnie jak nie miała szans wejść w dialog z publikacją Matuszewskiego. Wydaje się jednak, że za pomocą zręcznych gestów zabezpieczyła się przed tego typu atakami. Aby jednak je zauważyć, trzeba przeczytać jej prozę, która w niczym nie przypomina "gryzmołów” czy "epistoł" (Kolińska 27, 104), za to wydaje się oryginalną mitologią artystki o nachyleniu ekokrytycznym.

\section{Mitologia, self-esteem, totemizm}

„Opowiadając swoją historię, osoba nadaje szczególne znaczenie pewnym wydarzeniom (lub serii wydarzeń), które dzięki temu funkcjonują jako «jednostki znaczeniowe» albo [...] wartościowania" (Hermans, Hermans-Jansen 13). Ich podstawę stanowi dążenie do umacniania siebie. W ostatniej części rozważań pokażę, że 
opowieści Czajki, którym najczęściej przypisywano kłamstwo, nadmierną fantazję, baśniowość i puste znaczenie (Tomczok 105), odgrywają rolę wzmocnień bądź autoprowokacji, za pomocą których jej self-esteem zdołało podnieść się po doświadczeniu Zagłady.

Self-esteem, to trudne do przełożenia pojęcie, wykładane niekiedy jako poczucie własnej wartości oraz mocy (Czywkin 275), wydaje się odwrotnością procesu stygmatyzacji. Dlatego, aby zobaczyć jego działanie, warto zaaranżować sytuację możliwą głównie dzięki istnieniu takich struktur recepcyjno-literackich jak wspomniane opowieści z lat pięćdziesiątych i sześćdziesiątych, pozwalających oddzielnie zobaczyć proces powstawania stereotypów i autonarrację, która z nimi walczy. Self-esteem nie jest raz na zawsze dane, ale tworzy się w odpowiedzi na zmagania z doświadczeniami. Niekiedy okazuje się też rezultatem mocowania się jednostki z niekorzystną wizją wytworzoną na jej temat przez otoczenie. Takiej wizji nie znajdziemy w powieściach Czajki. Ich bohaterką jest córka bogatego żydowskiego kapitalisty z Warszawy, która wikła się w szereg zabawnych przygód, czyniących z jej życia coś w rodzaju błyskotliwej anegdoty, komedii omyłek, a niekiedy i tragifarsy. Wszystkie trzy powieści będące przedmiotem analizy (Ocalit mnie kowal, Król wę̇̇y $i$ salamandra oraz Dubo... Dubon... Dubonnet) łączy jedna strukturalna cecha (najmniej obecna w pierwszej z nich): opowiadanie o przygodach młodości w trybie retrospektywy. Jest ono jednak zaznaczone oszczędnie, niemniej pozwala ustalić, czy w owej „starczej” narracji pisarka komentuje krążące na swój temat obiegowe opinie, czy też raczej poddaje je krytyce wyłącznie za pomocą narracji symbolicznej.

W Ocalit mnie... i Królu węży... Czajka chętnie sięga po wyobrażoną postać, za pomocą której opisuje siebie. Ma ona cechy bytu autonomicznego i proponuje indywidualne wartościowanie siebie, odgrywa też ważną rolę $\mathrm{w}$ procesie autoterapii (Hermans, Hermans-Jansen 139). Opowiadając o czasach pobytu na pensji, a później w środowisku studentów filozofii Uniwersytetu Warszawskiego, bohaterka Króla węży... zmaga się z poczuciem wstydu, stygmatem nieuctwa, wyobrażeniem, że nie podoła ani nauce, ani maturze. Postacią, która przychodzi jej zawsze z pomocą, jest ojciec, ten sam, którego później będzie musiała symbolicznie zabić, Wilhelm Szwarz, tytułowy król węży:

W pewnej chwili głowa ojca wśród smug, kreślących zawiłe ornamenty, wydała mi się jakaś nierzeczywista.

- Och, tatusiu! Wyglądasz jak król węży! Ty na pewno jesteś królem węży ... a, a ja - zaniepokoiłam się nagle - chyba salamandrą.

- Salamandra żyje w ogniu - tajemniczo powiedział tatuś.

- Czyż naprawdę można żyć w płomieniach? Nie, nie wierzę! To niemożliwe.

- Nie wierzysz? Zapytaj swoich profesorów na uniwersytecie, to jest dawno stwierdzone. Wiadomo od wieków, że salamandra lubi ogień, płomienie jej nie parzą... przeciwnie, to jest jej żywioł... Ty właśnie jesteś salamandrą! 
[...] - Trudno, jeśli mnie sama rozpoznałaś, to ci teraz powiem. Ale pamiętaj, nie mów nikomu. Słyszysz? Ani mamusi, ani Ewie, ani koledze Hertzowi... Jestem królem węży... ja, ja prowadzę podwójne życie - tam paprocie, brzegi strumienia i wikliny, tam w lesie, tamto, tu, w domu, to (Czajka 1968: 225-226, podkr. M.T.).

We wspomnieniach z gett $\mathrm{w}$ Warszawie i Otwocku oraz ukrywania się w lasach magicznej postaci ojca już nie ma. Zastępuje ją młoda chłopka, Danusia. Pewnego razu, podczas nalotu gestapo na dom, w którym obie się ukrywają, Czajka z przystawionym przez Niemca pistoletem do skroni, na pytanie o tożsamość, udziela następującej odpowiedzi:

Kim jestem?... Boże, wielki Boże... gdybym mogła stać się prawdziwą czajką... byłabym ptakiem, nikt by nie mógł posądzać mnie o żydostwo. Pofrunęłabym, schowała się w krzakach...

Oszalała z przerażenia, na wpół obłąkana, jakimś piskliwym głosem zaskrzeczałam:

- Jestem czajka, ptak wodny.

- Was sagt sie? - zwrócił się Niemiec do tajniaka.

- Sie sagt, dass się ein Wasservogel ist - przetłumaczył.

- Was, ein Wasservogel?! - Niemiec jeszcze bliżej przysunął rewolwer do mojej skroni (Czajka Stachowicz 2013: 179).

Obie figury - płaza i ptaka - mają charakter totemiczny. Stanowią ochronę przed złem, gwarantującą ukrycie się i przetrwanie, są rodzajem skrytki, osłony, obiektu magicznego i jednocześnie zastępują prawdziwy obiekt. Próbując ustalić, dlaczego pisarka sięgnęła akurat po te, a nie inne gatunki zwierząt, należałoby zawierzyć Claude Lévi-Straussowi, sugerującemu podążanie za intuicją ludzi z plemienia Nuer, których pomysły nazewnicze (bliźnięta jako ptaki) na pierwszy rzut oka wydają się sprzeczne. Zarówno węże, jak i ptaki oraz niektóre gatunki roślin mogą być „widomymi znakami wyjątkowo potężnej działalności duchów" (Lévi-Strauss 106). Ich znaczenie jest także apotropaiczne, mają one na celu odpędzić złe moce, ochronić przed katastrofą, odegnać groźbę śmierci (Domańska 42). To samo znaczenie będzie mieć czerwony szalik z portretu Czajki namalowanego w latach trzydziestych przez Mojżesza Kislinga (reprodukcję na okładce Dubo..., Dubon..., Dubonet zamieściło Wydawnictwo Literackie, a na ilustracji do książki przetworzyła go Maja Berezowska). Wszystko to jednak nie są proste symbole, a nadane im przygodnie znaczenia wynikają przede wszystkim ze spontanicznych działań podmiotu. Czajka interesowała się określonymi gatunkami zwierząt nie dlatego, że wzbudzały w niej wyjątkowe zaciekawienie (pisała także o kotach, myszach, psach czy kurach), ale dlatego, że została doprowadzona do zainteresowania nimi na skutek postaw rytualnych, jakie zachowuje się wobec określonych gatunków (Lévi-Strauss 91). W przypadku ptaków i salamander chodzi o dzikość, ale też o komunikowanie ludziom, 
za sprawą utrwalających ich wizerunek narracji, istnienia świata cudów bez ich udziału (Montgomery 14-15). To właśnie te wyobrażenia stały się dla pisarki obroną przed stygmatyzującą jej wizerunek artystyczny powojenną krytyką literacką.

\section{Podsumowanie}

Istotą indywidualnej mitologii artystycznej Czajki była walka ze stygmatami poprzez zastępowanie obiegowych przekonań obrazami symbolicznymi, znacznie lepiej tłumaczącymi rodowód sztuki i o wiele bardziej opornymi wobec stygmatyzacji niż wiele rozwiązań należących do dyskursu metakrytycznego. Odporna na ogień salamandra czy metamorfoza kobiety w ptaka pod wpływem zagrożenia Zagładą stały się podstawą imaginarium holokaustowego. Zdają się też być rzadko spotykanym przykładem obrony Ja przed przytłaczającą rzeczywistością, ułatwiającym - niemożliwe w gruncie rzeczy - wyjaśnienie jej funkcjonowania i zrozumienie, zupełnie przypadkowego, ocalenia.

Znacznie trudniejsze wydaje się wyjaśnienie na tym tle pseudonimu literackiego pisarki, która z czasem przestała podpisywać książki imieniem i nazwiskiem, zastępując je krótkim i wymownym słowem „Czajka”. W powieści wspomnieniowej Ocalit mnie... jego użycie tłumaczy się za pomocą anegdotycznej historii o niepoczytalnej siostrze Kowala z Dobrzyńca, Stefanii Czajce, która miała „użyczyć” pisarce swojej tożsamości. Tożsamość ta pozwoliła jej przetrwać wojnę, zaistnieć w świecie literatury i odsunąć od siebie stygmat Żydówki.

Mitologia artysty z jednej strony może być rezerwuarem stereotypów, z drugiej potrafi ochraniać niczym totem przed katastrofą. Pomaga także poharatanemu Ja pozbierać się po doświadczeniach Zagłady i ustanowić działanie prewencyjne ante factum (Domańska 43).

\section{BIBLIOGRAFIA}

Czajka [Stachowicz Izabela]. Król węży i salamandra. Warszawa: Czytelnik, 1968.

Czajka Stachowicz, Izabela. Dubo..., Dubon..., Dubonnet. Kraków: Wydawnictwo Literackie, 1970.

Czajka Stachowicz, Izabela. Ocalit mnie kowal. Warszawa: W.A.B., 2013.

Czywkin, Elżbieta. Stygmat społeczny. Warszawa: PWN, 2007.

Czywkin Elżbieta, Rusaczyk Marzena, red. „Gorsi inni” - badania. Białystok: Trans Humana, 2008.

Domańska, Ewa. „Sprawiedliwość epistemiczna w humanistyce zaangażowanej”. Teksty Drugie 1 (2017). S. 41-59.

Godzic, Wiesław. Znani z tego, że są znani. Celebryci w kulturze tabloidów. Warszawa: Wydawnictwa Akademickie i Profesjonalne, 2007. 


\section{MARTA TOMCZOK, MITOLOGIE CZAJKI}

Hermans Hubert J.M., Hermans-Jansen Els. Autonarracje. Tworzenie znaczeń w psychoterapii. Przeł. Piotr K. Oleś. Warszawa: Pracownia Testów Psychologicznych Polskiego Towarzystwa Psychologicznego, 2000.

Janion, Maria. „«Prze-pisać» los Ginczanki”. Araszkiewicz, Agata. Wypowiadam wam moje życie. Melancholia Zuzanny Ginczanki. Warszawa: Fundacja OŚKa, 2001. S. 5-10.

Janion, Maria. „Jestem po prostu starą kobietą”. Rozm. przepr. K. Szczuka. OŚKa - Biuletyn. 4/1. 2001/2002. S. 14-17.

Kolińska, Krystyna. Szatańska księżniczka. Warszawa: Krajowa Agencja Wydawnicza, 1992.

Kott, Jan. „Przedmowa”. Czajka [Stachowicz Izabela]. Ocalit mnie kowal. Warszawa: Czytelnik, 1956. S. 5-7.

Lévi-Strauss, Claude. Totemizm dzisiaj. Przeł. Aniela Steinsberg. Warszawa: KR, 1998.

Mandal, Eugenia. Podmiotowe i interpersonalne konsekwencje stereotypów związanych z płcią. Katowice: Wydawnictwo Uniwersytetu Śląskiego, 2004.

Matuszewski, Ryszard. Alfabet. Wybór z pamięci 90-latka. Warszawa: Iskry, 2004.

Montgomery, Sy. Ptakologia. Przeł. Adam Pluszka. Warszawa: Marginesy, 2018.

Osęka, Andrzej. Mitologie artysty. Warszawa: Państwowy Instytut Wydawniczy, 1978.

Sołowianiuk, Paulina. Ta piękna mitomanka. O Izabeli Czajce-Stachowicz. Warszawa: Iskry, 2011.

Spitzer, Manfred. Jak uczy się mózg. Przeł. Małgorzata Guzowska-Dąbrowska. Warszawa: PWN, 2007.

Taborska, Agnieszka. „Wszystko to brzmi jak bajka”. Prassinos, Gisèle. Twarz muśnięta smutkiem. Przeł. Agnieszka Taborska. Warszawa: PIW, 2005.

Tokarska-Bakir, Joanna. Et(n)ologia piętna. Gdańsk: Gdańskie Wydawnictwo Psychologiczne, 2005.

Tomczok, Marta. „Czajka (nad)zwyczajna. Perspektywa ekokrytyczna w narracjach o Zagładzie Izabeli Czajki Stachowicz". Narracje o Zagładzie 3 (2017). S. 103-120.

Umińska, Bożena. Postać z cieniem. Portrety Żydówek w polskiej literaturze od końca XIX wieku do 1939 roku. Warszawa: Sic!, 2001.

Uniłowski, Zbigniew. Wspólny pokój i inne utwory. Oprac. B. Faron. Wrocław-Warszawa-KrakówGdańsk: Zakład Narodowy imienia Ossolińskich, 1976.

Witkiewicz, Ignacy. Pożegnanie jesieni. Kraków: Zielona Sowa, 2010. 